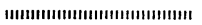

\title{
微小電子源と真空マイクロエレクトロニクス
}

\author{
別 井圭一 \\ (株)富士通研究所 严243-01 厚木市森の里若宮 10-1
}

(1991 年 12 月 3 日受理)

\section{Micro Cathode and Vacuum Microelectronics}

Keiichi Betsui

Fujitsu Laboratories LTD.

10-1, Morinosato-Wakamiya, Atsugi 243-01

(Received December 3, 1991)

\begin{abstract}
半導体の微細加工技術を応用した新しい微小電子源の開発が進んでいる。とのミクロンサイズの微小電子 源を利用して，超微細な電子管素子や，フラットパネルディスプレイなどをつくる技術が注目されている。 ての技術は真空電子を用いて, 従来の半導体素子では達成できない新しい機能をむった電子デバイスをめざ すすのであり，真空マイクロエレクトロニクスという新しい技術分野を形成しつつある。ととでは，筆者の 研究を中心にての分野について解説する。
\end{abstract}

\section{1.はじめに}

半導体デバイスの目ざましい進歩にともない，微細加 工技術む著しい進歩を遂げている。この微細加工技術は 単に半導体素子の作製に応用されるだけでなくさまざま な分野に応用されている。従来の機械加工では不可能な 超微細な構造を作ることができ，しかむ一度に大量生産 ができるというとの技術の特長を活かすととにより，従 来の製造技術では困難な点を克服するととができる。電 子源にむとの半導体の作製技術を応用し，新しいタイプ の陰極を作製しようという試みが活発化している。

電子源のうち熱㓌極は実用電子源として多くの用途に 実用されているが，高温状態で動作するため微小化に向 かず半導体の技術の応用は難しい。一方, 電界放出陰極 を始めとする冷陰極は半導体技術とのマッチングがよく 微小化により従来にない特性の陰極が構成できる可能性 がある。

微小電子源の特長はまずそれがきわめて小さいととで あり，独立な陰極を非常に高い密度で形成できることで ある。さらに院極だけでなく電極などの構造む半導体微 細加工技術を応用したマイクロマシン技術で同時に作製 するととあ可能である。従来の電子管では, 熱陰極が用
いられ，制御電極などもすべて機械加工，機械組立てに より作製されていた。CRT などの一部の応用を除いて 電子管が半導体にその座を明け渡したのは, 機械加工, 組立てによる信頼性の低さ, 量産性の悪さ, 小型化の限 界などが原因であり，電荷移送媒体としての真空の特性 が悪いわけではない。実際，半導体などの固体内部の電 子と異なり真空中では電子に高いエネルギーを与えた り，さらに偏向や収束させるととが容易である。また放 射線，温度などの影響を受けないために耐環境性が強い などの多くの利点をむっている。

近年, 半導体の微細加工技術を用いることにより従来 の電子管のもっていた欠点を克服し，まったく新しい電 子デバイスをつくる技術, 真空マイクロエレクトロニク スが注目されている 特長を活かし, (1) 超高速素子, 高周波数增幅素子, (2) 耐環境素子 (高温環境, 放射線環境, 宇宙環境), (3) 高精細薄型ディスプレイ，(4)電子ビーム応用技術 (電子線露光, 電子線計測, 自由電子レーザー) などの さまざまな応用が考えられている。

真空マイクロエレクトロニクスの研究はてれまで主と して米国が中心に行われてきた。最近, 微小電界放出 陰極が実用レベルに達したので, 研究者の数が増え, 


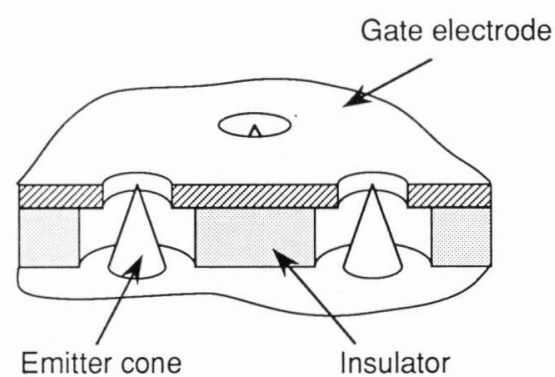

(a)

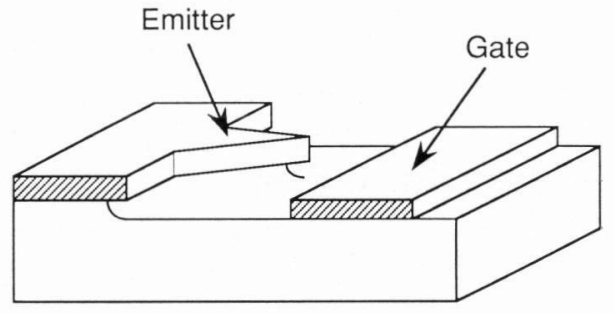

(b)

図 1 電界放出陰極の構造

1988 年より真空マイクロエレクトロニクスの国際会議 あ開かれるようになった。昨年はこの国際会議が日本で 開催されたこともあって国内の研究も活発化している。 本稿では微小電子源とその応用について筆者の研究を中 心に解説する。

\section{2. 微小電子源の原理と構造}

微小電子源として最屯精力的な研究が続けられている のが電界放出陰極アレイである。微小電界放出陰極の構 造は図 1 に示すように，緹型と横型に大きく分類でき る。縦型は直径 1〜2 $\mu \mathrm{m}$ のゲート電極口の中に円錐形 のエミッタティップが垂直に置かれている。一方横型は 基板に平行にエミッタが配置されその前方にゲートが置 かれている。どちらの場合むゲートをエミッタに対して 正電位とすると，尖ったエミッタ先端に大きな電界が発 生する。表面の電界が $10^{7} \mathrm{~V} / \mathrm{cm}$ 程度になるとティップ 内部の電子は表面のポテンシャル障壁をトンネル効果に より通過し真空中に飛び出してくる。従来の電界放出陰 極はタングステンなどの高融点金属線の先端を電解研磨 法により尖らせて作るが，その先端の曲率半径は 0.1 $\mu \mathrm{m}$ 程度と比較的大きく数 $\mu \mathrm{A}$ の放出電流を得るのに数 $\mathrm{kV}$ の電圧を必要とした。それに対して, この微小電界 放出陰極では先端の曲率半径は $10 \mathrm{~nm}$ 程度と小さく, またティップ先端とゲート電極の間隔は約 $1 \mu \mathrm{m}$ と近い ので, $100 \mathrm{~V}$ 程度の引出し電圧で数 $\mu \mathrm{A}$ の放出電流を取 り出すととができる。個々の陰極としての放出電流值は せいぜい $100 \mu \mathrm{A}$ 程度であるが，放射領域が数 $\mu \mathrm{m}$ のた め多数の陰極をアレイ状に配置することにより平面状の 陰極として動作可能となり, 高い放出電流密度を得るこ とができる。一方横型は，基本的に平面形状の加工なの で半導体の微細加工プロセスをそのまま活かせる。また 薄膜を用いることで膜面に垂直な方向の曲率を非常に小 さくできる。さらに絶縁性の基板を用いることで電極間 の静電容量を小さくできるために高速の増幅素子を作る 場合に有利である。微小電子源としてはここで述べた電 （a）は縦型，（b ）は横型

界放出㓌極以外に接合のアバランシェ降伏を用いるも $の^{4,5)}$, MIM 構造のトンネル電子を用いるもの などの さまざまな方式が提案，検討されている。

\section{3. 微小電界放出陰極の作製方法}

半導体の微細加工技術が進歩したといっても，通常の 光による露光技術ではせいぜい $0.3 \mu \mathrm{m}$ 程度が解像でき るにすぎない。一方, 微小電界放出院極に必要なティッ プの曲率半径は $20 \mathrm{~nm}$ 以下であり，乙れを達成するに は特殊な作製プロセスが必要である。

縦型の電界放出陰極は SRI の Spindt らにより初め て作製された 方法を図 2 に示す。導電性基板（シリコン）上に絶縁 (a)



(b)

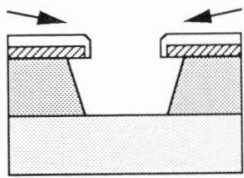

(c)
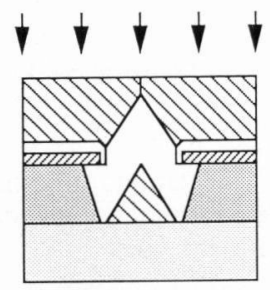

(d)



Gate aperture formation

Sacrificial layer deposition

Emitter material deposition

\section{Lift off}

図 2 Spindt らが最初に用いた電界放出陰極の作 製プロセス 
膜, ゲートとなる金属膜を成膜する。金属膜, 絶縁膜に 円形の小さな穴を通常のフォトプロセスで形成する。そ の後アルミナなどの犠牲層を基板に対して浅い角度で蒸 着する。との工程によりゲートロ径は縮小するとともに ゲート電極膜は犠牲層に覆われる。その後, モリブデン などのエミッタとなる金属を基板に対して垂直に蒸着す る。ゲートロは蒸着とともに小さくなるので穴の内部に 円錐型のエミッタティップが形成できる。このあと犠牲 層のエッチングにより不要のモリブデンを除去して素子 は完成する。

一方, NAL の Gray らはシリコンの結晶面方位異 万性エッチングを用いて同じような構造を作った ${ }^{8)}$ 。シ リコンの表面に $\mathrm{SiO}_{2}$ などでエッチング用のマスクを形 成し, 異方性エッチング液（ $\mathrm{KOH}$ 水溶液など）を用い てシリコンをエッチングしマスク下部にピラミッド型の シリコンエミッタを形成する方法である。われわれはこ のエッチングによるエミッタ形成法を発展させて特性の よいシリコンエミッタを作製できだ9。ここエミッタ作 製プロセスを図 3 に示す。（a）シリコン基板上に熱酸化 膜を形成する。（b）つぎにてれをリアクティブィオン エッチング (RIE) により円形にパターン形成する。 (c)これをマスクとしてシリコンを RIE によりエッチ ングしエミッタティップを形成する。エッチング時の条 件を適当に選び，マスク下部に適当なサイドエッチング が生じる条件で RIE を行うと, 円錐形状のエミッタが (a)



(b)

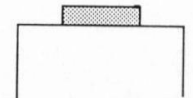

(c)

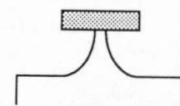

(d)

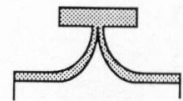

(e)

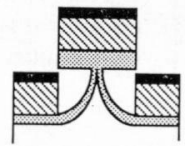

(f)

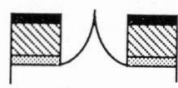

(g)

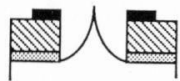

Thermal oxidation

Mask formation

Silicon etching

Thermal oxidation

Insulator and gate metal deposition

Lift off

\section{Gate formation}

図 3 RIE と酸化プロセスによるシリコン FEA の作製プロセス
形成されてくる。そこで, 完全にマスクが取れる前にエ ッチングを終了する。この状態ではエミッタティップ先 端は尖っていない。(d)との後, シリコンを熱酸化しエ ミッタティップ表面に酸化膜を形成する。この処理によ りエミッタティップ内部にシリコンのきわめて鋭い先端 が形成される。(e)その後, 絶縁膜およびゲート電極膜 を蒸着する。(f)フッ酸に浸漬してエミッタティップ表 面の熱酸化膜を除去し, マスクとその上にある絶縁膜之 電極膜のリフトオフを行う。 $(\mathrm{g})$ 電極パターンを形成し 素子は完成する。この方法はエッチング工程がすべてド ライプロセスであり, エッチングの一様性, 再現性がウ エットエッチングによる方法と比較し大きく改善され た。またエッチングマスクを蒸着時にゲートロの形成に 用いるためエミッタティップをきわめて正確にゲートロ の中心に形成できる。さらにての方法はシリコンだけで なくタンタルなどの金属エミッタの形成にも適用でき る ${ }^{10)}$ 。RIE による作製ではエッチング条件を適当に選 択するととによりエミッタティップの形状をコントロー ルできる。図4(a) はエッチング深さとサイドエッチン グの比を約 2 としたときの RIE 後のエミッタティップ の SEM 写真である。なめらかに凹んだ稜線をむつ円錐 形のエミッタティップが形成できた。図 4 (b) はゲート 径を縮小し特性を向上させることを目的として，2 段 階の RIE により形成した砲弾型エミッタティップの SEM 写真である ${ }^{11}$ 。1 段目のエッチングでサイドエッ チングにより先端を形成し 2 段目のエッチングは垂直 エッチングを行いエミッタの高さを高くしている。図 5 （a）はこの方法で作製したシングルティップ電界放出 陰極の SEM 写真である。熱酸化による先鋭化により ティップ先端の曲率半径が $10 \mathrm{~nm}$ 以下の非常に鋭いエ ミッタティップが形成できる。図 5 (b) は砲弾型エミッ タアレイの SEM 写真である。エミッタティップの間隔 は $4 \mu \mathrm{m}$ であり, 100 個 $(10 \times 10)$ と 6400 個 $(80 \times 80)$ の陰極を集積した。ゲート口径は砲弾型のもので約 2 ミ クロンである。こ机らの陰極の電子放出特性については 後で述べる。

一方横型の電界放出陰極を作製する際には, 基本的に 平面形状の加工なので半導体製造プロセスがそのまま活 かせるが，一回の露光とエッチングでエミッタティップ 先端を作製すると先端の曲率半径は解像限界から光学的 にきまる曲率半径より小さくならない122。そこで先端を 形成するのに図 6 に示すように一つの辺ごとに露光と エッチングを繰返して 2 回のエッチングにより先端を形 成する手法をとっている ${ }^{13,14)}$ 。これにより先端の曲率半 径は露光時の解像度によらず, エッチング時のパターン エッジの滑らかさで決定され，滑らかであるほど先端の 


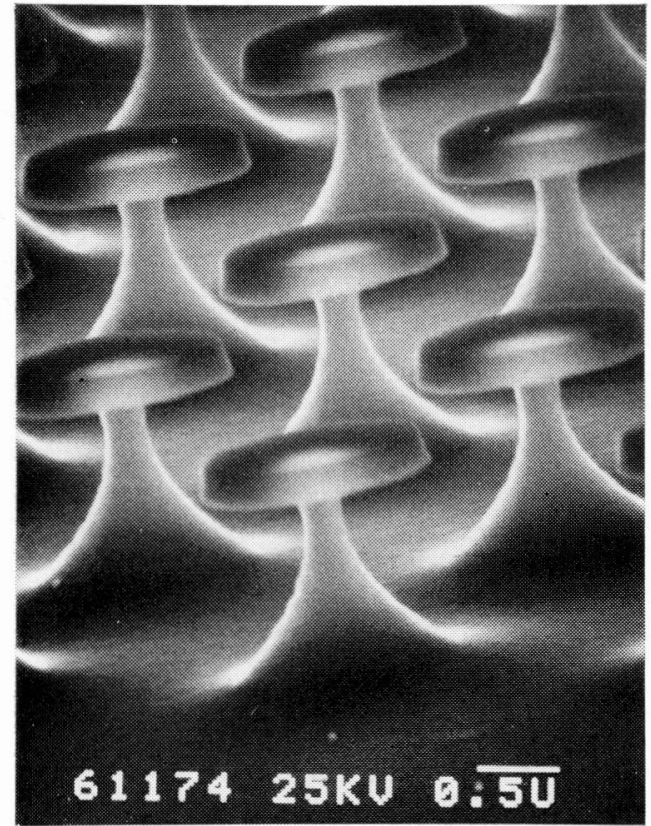

(a)



( b

図 4 RIE 後のエミッタの SEM 写真（a）は円錐型エミッタ（b ) は砲弹型エミッタ

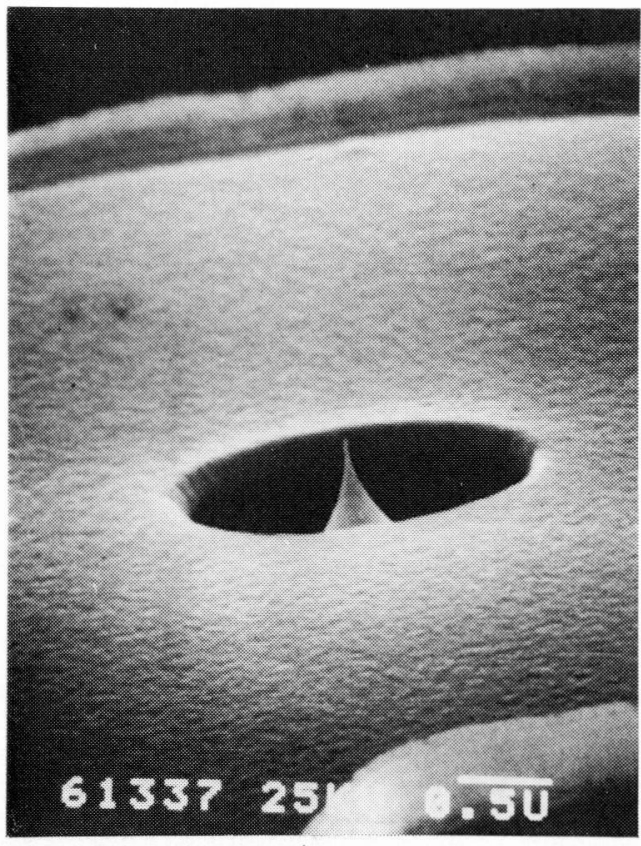

(a)

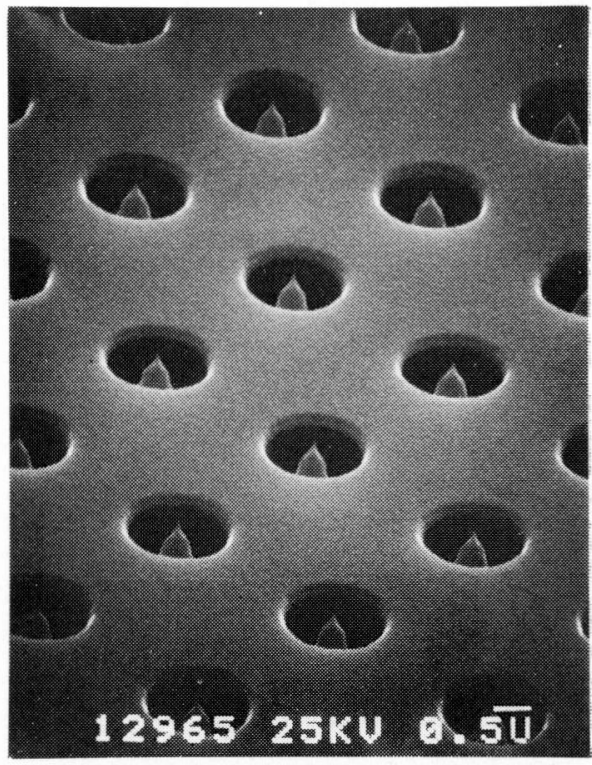

(b)

図 5 シリコン電界放出陰極の SEM 写真 
曲率半径は小さくなる。また横型ではエミッタとゲート を同一のマスクで形成するとゲートとエミッタ間隔を解 像度以下に近づけられない。そこでエミッタを形成した 後とれを用いて自己整合プロセスでゲート電極を形成す

(a)

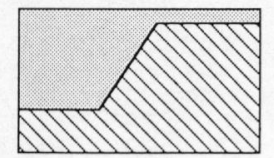

1 st resist patterning

(b)

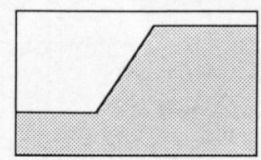

1st metal etching

(c)

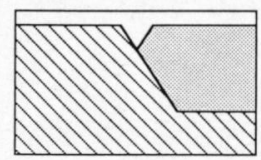

2nd resist patterning

(d)

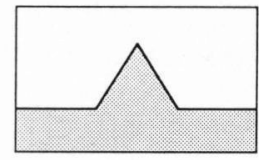

2nd metal etching

図 62 回露光一エッチングによる横型エミッタの 作製プロセス

(a)

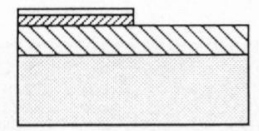

Sacrificial layer and emitter etching

(b)



Insulator etching

(c)

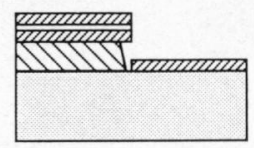

\section{Gate deposition}

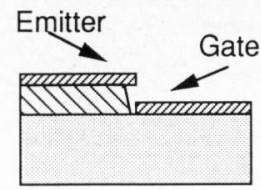

\section{Lift off}

図 7 セルフアラインプロセスによるゲート電極の 作製プロセス
る方法をとっている ${ }^{14 \sim 17)}$ 。図 7 亿自己整合ゲート作製プ ロセスの一例を示す。エミッタ先端を利用して蒸着によ りゲートエッジを形成する。図の例ではエミッタより ゲート電極を下に形成した構造であるが，電子を上方に 放出させたい場合はゲート下部に絶縁膜を置き，エミッ タより上方に位置させる例あある ${ }^{15,16)}$ 。ゲートエミッタ 間の距離はエミッタの形成時のサイドエッチングの量と 基板のエッチング量などでコントロールしている。

\section{4. 電子放出特性}

われわれの作製したシリコン電界放出陰極の電子放出 特性を以下に示す ${ }^{10)}$ 。図 8 亿 6400 ティップアレイ陰極 の放出電流, ゲート電流と引出し電圧の関係を示す。放 出電流は $80 \mathrm{~V}$ で $8 \mathrm{~mA}$ が得られた。この構造の電界放 出陰極ではゲート電流はアノード電流の $0.1 \%$ 程度であ り放出電子の大部分を利用することができる。シリコン 単陰極では最大放出電流として $50 \mu \mathrm{A}$ 程度が得ら机て いる。また電流密度は 100 ティップアレィで $50 \mathrm{~A} / \mathrm{cm}^{2}$ 程度が得られている。

電界放出型の陰極では放出電流の安定性が大きな問題 となる ${ }^{18)}$ 。電界放出陰極の電流変動の原因は，（1）エ ミッタ表面の吸着ガス分子などの移動，(2) 真空中の残 留ガス分子のエミッタ表面への付着あるいは脱離などが ある。どちらも表面の仕事関数の局所的な変化を生じ, 放出電流が変化する。上記の作製方法で作ったシリコン 単陰極では $50 \%$ 程度の電流変動があるが, 多数の陰極 を集積して同時に動作させると, 電流変動は統計的に平 均化される。実際, 6400 ティップアレイの電流変動は $1 \%$ 以下となっている。しかし個々のエミッタの電流変 動が問題になるような増幅器などへの応用では電流の安 定性をさらに高める必要がある。そのためにはエミッタ 材料の検討，ティップ表面の脱ガス処理 ${ }^{19}$ などの検討が 必要である。このような微小電界放出陰極では 10,000 時間程度の連続動作の報告 ${ }^{20)}$ あるが, 上述したように

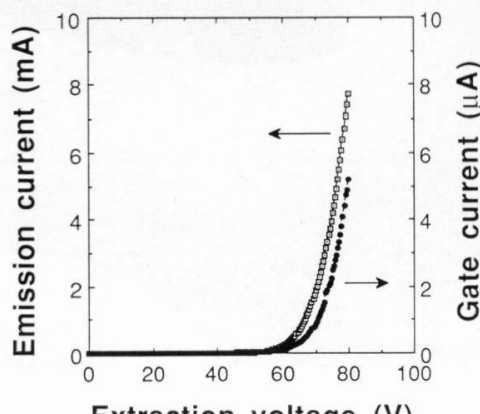

Extraction voltage $(\mathrm{V})$

図 86400 ティップアレイの電子放出特性 

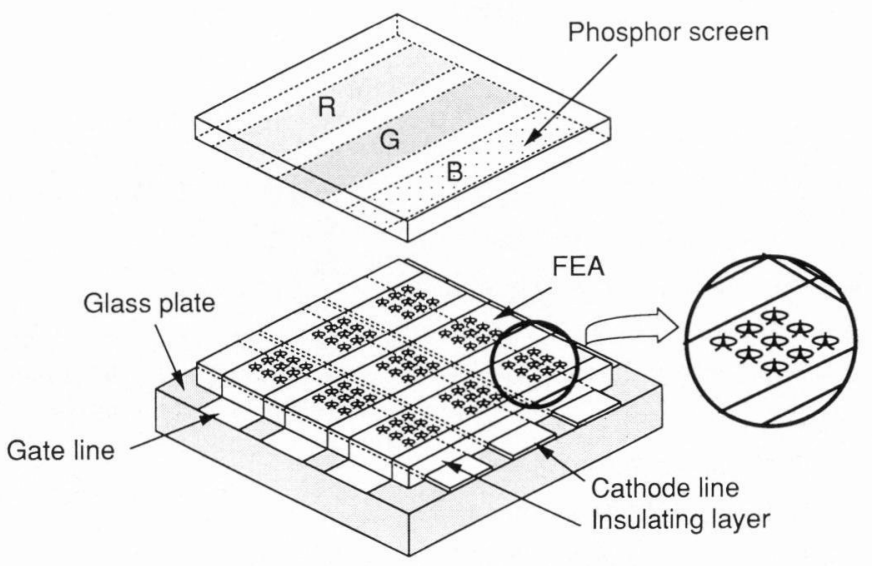

図 9 電界放出陰極を用いたフラットパネルディスプレイの構造図

陰極の寿命は表面の状態，残留ガスなどに左右されるた め，今後十分な検討が必要である。

\section{5. 応用}

この微小電子源の応用として最む期待されているのが フラットパネルディスプレイである ${ }^{21,22)}$ 。電界放出㓌極 アレイを用いたフラットパネルディスプレイの構造を図 9 に示す。カソード電極ラインとゲート電極ラインによ り X-Y マトリックスを構成する。その交差部分に電界 放出陰極アレイを配置する。駆動は電子放出特性に図 8 に示すような非線形性があることを利用する。特定の ゲートラインとカソードラインに電圧を印加することに よりいわゆる単純マトリックス駆動が可能である。電界 放出陰極は非常に小さいので，1画素あたり多数のエミ ッ夕を配置することにより，個々のエミッタの電流変動 は平均化され目で見てもほとんどわからないほどに低減 できる。さらに個々のエミッタの久陥による動作不良に 対して非常に大きな長性が期待できる。フランスの LETI は6インチのモノクロディスプレイを試作してお り，昨年はフルカラーのものも発表した ${ }^{23)} 。$

一方, 真空電子の高速性を利用し, 増幅素子を構成す れば高速動作が期待できる。微小電界放出院極を用いた 増幅素子としては図 10 に示すような構造が提案されて いる。図 10 (a ) は緹型の素子のゲート電極の外側に陽 極を配置した構造で，エミッタから放出された電子は反 転して陽極に到達する ${ }^{24)}$ 。実際，われわれはこの構造の 微小三極管を上記の作製プロセスで試作した。単陰極の 素子で相互コンダクタンス $0.2 \mu \mathrm{s}$ が得られている (b)はアノードをエミッタ上方に配置した垂直型であ る。この形はアノードにより密閉されるため非常に小さ い真空キャビティが構成できる ${ }^{25)}$ 。この構造の三極管は アノード，エミッタ間の距離を小さくできるために電子 (a)

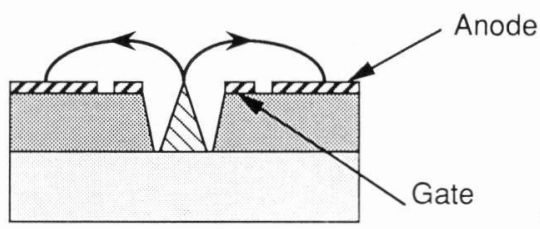

(b)

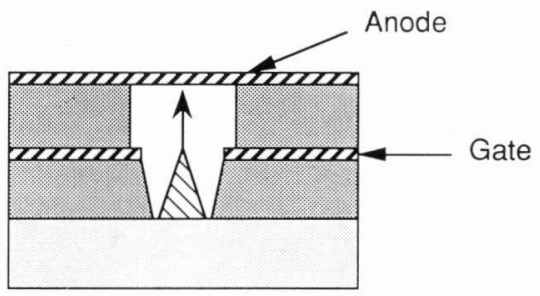

(c)

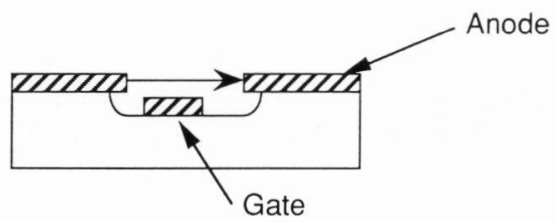

図 10 電界放出陰極を用いたマイクロ三極管の 構造

の走行時間は小さくなるが,一方でゲートエミッタ間の 容量が大きいために高速動作のためには大きな相互コン ダクタンスが必要になる。（c）は横型院極を用いて三極 管を構成した場合の構造である。絶縁性の基板を用いる ことにより各電極間の静電容量を小さくでき高速動作に 有利である。ゲート電圧に対するアノード電流の非線形

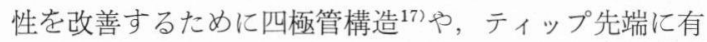
効に電界が加わるようにゲート電極を立体的に構成し， 


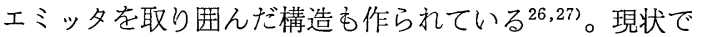
は放出電流が小さいために相互コンダクタンスは小さい が, 今後電極材料, 作製プロセスなどの改良により性能 の向上が望まれる。

\section{6. むすび}

電界放出陰極の微小電子源についてわれわれの研究を 中心にその特長, 作製方法, 特性などを紹介した。微小 電子源の研究はまだ始まったばかりであり, 素子の性能 あまだ黎明期にあるといえる。しかし一方で，ディスプ レイを始めとして非常に広範囲の応用が期待できるデバ イスであり，今後の素子性能の向上が望まれる。実用化 に当たっては, 陰極の安定性を高めるのが最重要課題で あり, 安定性を改善するための地道な努力が必要であ る。研究者の数屯確実に増加しており今後の開発の加速 されることが期待できる。

\section{文献}

1）たとえば, 横尾邦義 : 真空 32, 63 (1989).

2）南日康夫, 内海孝夫 : 応用物理 57, 1421 (1988).

3）伊藤順司：応用物理 59, 164 (1990).

4) G. G.P. van Gorkom and A. M.E. Hoeberechts : Vacuum Microelectronics 89, 41 (1989).

5) T. Tsukamoto, N. Watanabe and M. Okunuki : Vacuum Microelectronics 89, 65 (1989).

6）横尾邦義, 小野昭一：“トンネル現象の物理と応 用”（培風館, 1987) p. 79 .

7) C. A. Spindt, I. Brodie, L. Hummphery and E. R. Westerberg: J. Appl. Phys. 47, 5248 (1976).

8) H.F. Gray: Proc. 29 th Intl. Field Emission Symp. Aug., 111 (1982).

9）別井圭一：電子情報通信学会秋季全国大会講演論
文集，5-282 (1990).

10) S. Fukuta and K. Betsui : Technical Digest of IVMC 91, 144 (1991).

11) K. Betsui : Technical Digest of IVMC 91, 26 (1991).

12) 伊藤順司 : 第 50 回応用物理学会学術講演会予稿 集, 484 (1989).

13）藤原ちづる，石井浩市，蘭 宗樹：第 51 回応用 物理学会学術講演会予稿集, 542 (1990).

14) 西村則雄, 金丸正剛, 伊藤順司, 中田久士, 渡辺 照男, 伊藤茂生 : 第 38 回応用物理関係連合講演 会予稿集，525(1991).

15）金子 彰, 菅野 亨, 富井 薫: 電子情報通信学 会秋季全国大会講演論文集，5-286 (1990).

16) A. Kaneko: Technical Digest of IVMC 91, 50 (1991).

17) H. Komatsu : Technical Digest of IVMC 91, 48 (1991).

18）たとえば，安達 洋: 真空 29, 13 (1986).

19) C. Oshima and A. Ohtuka : Technical Digest of IVMC 91, 102 (1991).

20) C. A. Spindt, C. E. Holland and R. D. Stowell : Appl. Surface Sci. 16, 268 (1983).

21) 富井 薰: フラットパネルディスプレイ'90, 103 (1990).

22) I. Brodie: Information Display 1, 17 (1989).

23) R. Meyer: Technical Digest of IVMC 91, 6 (1991).

24) H.F. Gray, G. J. Campisi : Mat. Res. Soc. Symp. Proc. 76, 25 (1987).

25) V. Makhov, N. Duzhev and A. Kozlov: Technical Digest of IVMC 88, 7-2 (1988).

26) H. H. Busta : Vacuum Microelectronics 89, 29 (1989).

27）濡木ちづる, 石井浩市, 蘭 宗樹 : 第 38 回応用 物理関係連合講演会予稿集, 525 (1991). 